\title{
Interest Cognition-Strategic Interaction-Feedback Assessment: Analysis of the Evolutionary Logic of Sino-Japanese Relations
}

\author{
Nan Lin (Corresponding author) \\ School of Political Science and Public Administration, \\ China University of Political Science and Law, PO Box 100088, Beijing, China \\ E-mail: squlinnan@126.com
}

Received: Oct. 9, 2020 Accepted: Oct. 26, 2020 Online published: Nov. 4, 2020

doi:10.5296/ijhrs.v10i4.17795 URL: https://doi.org/10.5296/ijhrs.v10i4.17795

\begin{abstract}
Sino-Japanese relations is an important and complicated bilateral relationship in Asian-Pacific region. The two countries are highly interdependent, but existing contradictions and competitions among many areas. It's a healthy bilateral relationship that promotes the development of China and Japan as well as regional stability. The specific "strategic basis" of Sino-Japanese relations lays a solid foundation for the stability and development of Sino-Japanese relations. Whether this foundation is solid or not, it completely depends on the consistency/inclusiveness extent of the cognition on core national interests and its strategic interaction and feedback assessment. Therefore, interest cognition, strategic interaction and feedback assessment are three elements to determine the evolution of Sino-Japanese relations. The three elements constitute an interactive logic loop, presenting distinct three stages of Sino-Japanese relations since normalization. The author takes the interactions of above three elements as analysis tool, and focuses on elucidating internal mechanism of the first two development stages of Sino-Japanese relations evolution, so as to explore the problems and roots among Sino-Japanese relations since 2012 and make brief analysis on the probability of reshaping the strategic basis of Sino-Japanese relations "struck by Donald John Trump".
\end{abstract}

Keywords: Sino-Japanese relations, core interest, interest cognition, strategic interaction, feedback assessment, strategic basis

The China-Japan Peace and Friendship Treaty signed by China and Japan in 1978 laid a legal foundation for the long-term peace, friendship, cooperation and mutual benefits of the two countries, marking they stepped on the path of strategic mutual trust (Wu, 2013). After 42 years, increasing contradictions and oppositions are emerging between China and Japan with 
intertwined conflicts. The reasons behind it are "strategic distrust" caused by "different political tradition, value system and culture" (Wang \& Li, 2012) or just the saying by realist "strategic trust is exactly an unrealistic goal, and the key for international relations is to enlarge common interests"? (Sun, 2009). Where is the crux between Sino-Japanese relations at present? And where is the developmental basis of their relations in the future? To answer these questions, the author thinks that analysis needs to be made in accordance with theory, history and current situation.

\section{Theoretical Framework and History Divisions of Sino-Japanese Relation ${ }^{1}$}

Interest Cognition - Strategic Interaction-Theoretical Framework of Feedback Assessment

This paper takes interest cognition, strategic interaction and feedback assessment as variates to constitute analysis framework. Based on the history and reality of Sino-Japanese relations, the research suggests that the essence of strategic distrust and common interest enlargement is interest cognition. Accordingly, interest cognition is based on strategic interaction and appears via feedback assessment. ${ }^{2}$ Therefore, the interactive function of these three elements are the core factors of their relations evolution. Hence, this paper defines interest cognition, strategic interaction and feedback assessment as follows. Firstly, interest cognition is their perception to each other's core interest, and the consistency/inclusiveness extent determines the shaping of bilateral relationship strategic basis, thus playing pivotal role in the nature of their relations regardless of cooperation, negativity or confrontation. ${ }^{3}$ At the same time, we shall not exclude the case that one country has wrongly judged national interest cognition subjectively. Just as what Robert - Jervis has said, "if one country wants to interpret other countries' behavior, it must try to observe the world with a vision of other countries and inspect the objective world in various different ways. It at least could avoid customary mistakes." (Jervis \& Qin, 2003). Secondly, as the basis of interest cognition, strategic interaction refers to that one country embodies strong subjective initiative in the strategic game with other countries among bilateral areas, regions and international levels, and it's also an important evidence of feedback assessment. Any party of strategic interaction will break the dynamic balance of mutual interest when adjusting external strategies, leading to the reshape of interest cognition of both sides. Finally, feedback assessment refers to that in the evolution of international system and landscape, both countries not only adjust own core interest, but assess each others' interests with feedback information generated by strategic interaction and decide strategic basis. It's worth noting that a period after the great evolution of international landscape, their relations in feedback assessment will present the state of

\footnotetext{
1 The historical division of Sino-Japanese relations in this paper refers to the division of historical period before and after the normalization of Sino-Japanese relations.

2 Sino-Japanese relations enjoys long history and intricacy-peace and opposition, interdependence and competition in reality. So their relation is bound to be a strategic relationship and the strategic interaction can be achieved on the basis of it.

3 The conception of core national interest in this paper refers to the "strategic interest" of national security and development. And the judgement of countries' interest cognition towards each other might be a little subjective. As for the definition and classification of national interest and behaviorist cognition, see: Hans J. Morgenthau, Politics Among Nations: The Struggle for Power and Peace, Beijing: Peking University Press, 2005, p. 10; Li Shaojun: National Interest, published in World Economics and Politics, issue 1, 2003, p.4-9; Wang Yizhou: Rethinking of National Interest, published in China Social Sciences, issue 2, 2002, p.160-170; Robert - Jervis: Perception and Misperception in International Politics, translated by Qin Yaqing, World Affairs Press, chapter 1, 2003.
} 
fluctuating. In a word, we can see from the figure 1 that interest cognition, strategic interaction and feedback assessment constitute an interactive logic loop, which provides analysis perspective to the crus of exploring into Sino-Japanese relations.

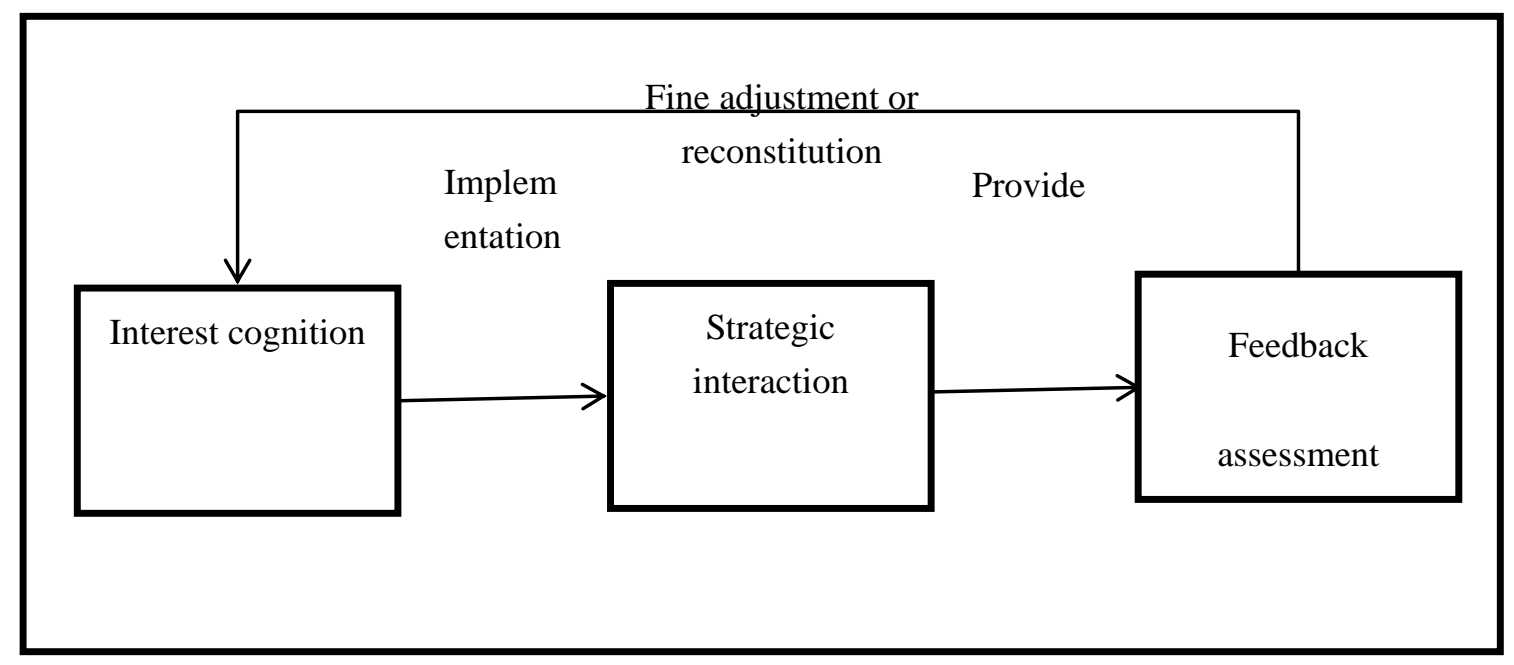

Figure 1. International Levels: Interest Cognition-Strategic Interaction-Theoretical Framework of Feedback Assessment

\section{Interest Cognition-Strategic Interaction-Feedback Assessment: Mechanism Analysis of Sino-Japanese Relations Evolution}

Looking back on over 40 years of establishing diplomatic relations between China and Japan, their relationship progresses steadily in twists and turns. Generally, they have made relative success. ${ }^{4}$ The author contends that the primary reason is that Sino-Japanese relations have clear strategic basis during the most period of history (1972-1989, 2001-2008), and the core is that both parties' consistency/inclusiveness upon core national interest have transcended divergences. At the same time, deriving from their common interest cognition, the strategic interaction of China and Japan plays a stable role in the strategic basis of above two historical stages, making the Sino-Japanese relations develop with a steady pace.

\section{(1) Cognition Analysis of Sino-Japanese National Interest}

Japanese national interest is referred to as "national interest" for short. For a long time after the World War II, Japan was rather low-profile when talking about national interest. ${ }^{5}$ Entering into the $21^{\text {st }}$ century, the Japanese edified by American realism international

\footnotetext{
${ }^{4}$ Compared with other regions characterized by complex geopolitics environment around the world, after the establishment of diplomatic relations between China and Japan, though they occasionally have frictions, direct military confrontation has never occurred. And they develop trade relations on the basis of equality and mutual benefit, facilitating the peace and development of this region jointly.

5 Although Japan always emphasizes on "national interest", just as the saying "national interest is the foundation of a country and its diplomacy", "misjudge national interest will lead to the demise of a country", "diplomatic relations can't be carried out if not know about one country's national interest". From the World War II to the beginning of 1980s, in Japan, due to that "strategy", "national interest" and other words in Japanese context contain the tone of militarism, they are almost regarded as taboo. See: Liu Jiangyong: Japan's View of National Interest, Foreign Strategy and Policy to China, Foreign
} 
political thought came to power (Liu, 2012). Defining Japanese realistic national interest is the urgent issues need to be solved by politicians and scholars of this generation (National security strategy, 2015). In 2013, Mr Abe's cabinet introduced the first Japanese Security Strategy report in history and clarified the national interest again in official form. From the content of this report, it's worth noting that Japan is defined as maritime state under the security assurance of Japan-U.S. alliance. It devotes to the peace, stability and prosperity of region as well as the world (National Security Strategy, 2013). Therefore, the author thinks that Japanese core national interest can be positioned on national security, economic prosperity, political interest and regional stability under the Japan-U.S. alliance.

China's view of national interest gradually forms in the evolution of international system and landscape. During the Cold War period, the core national interest that China gave first priority to was national political security, so the rest interests were in a subordinate position. 6 After Cold War, the international and domestic situation changed quickly. To seek development, China understood that economic interest became the most important national interest in the quest followed by security, political and cultural interest (Yan, 1996). In 2011, the Chinese government issued a white paper entitled China's Peaceful Development, clarifying the core national interests in official form for the first time, which were state sovereignty, national security, territorial integrity, national political system established by constitution of China and stability of society, and basic guarantee of sustainable development of economy and society (State Council of China, 2011). The author believes that China's core national interests can also be defined as national security (mainly on sovereignty independence and territorial integrity), political interest (national political system and social stability), economic development and regional stability. Since the reform and opening up, China has become the second largest economy in the world, which is mainly forged by the stable and sustainable economic development ensured by Chinese government.

(2) Interest Cognition - Strategic Interaction-Feedback Assessment: Mechanism Analysis of Sino-Japanese Relations Evolution

The author thinks that we can see from the definition of China and Japan towards core national interest, the historical evolution of Sino-Japanese relations contains the following mechanism: when China and Japan's consistency/inclusiveness of core national interest cognition transcends divergence with more common core interests, their strategic interaction will be in a state of cooperation. While they have few common interest, their strategic interaction will be in a state of coopetition/negativity. From the above two situations, the strategic basis of Sino-Japanese relations is still stable with different degrees. However, with

Affairs Review, $5^{\text {th }}$ issue, 2012, p. 13-14. Nobukatsu Kanehara, Principles of Strategic Diplomacy, Japan Business Press, 2011, issue 60, p. 61; Kohara Masahiro, National Interests and Diplomacy: The World System and Japan's Strategy, Japan Business Press, 2007, preface.

${ }^{6}$ In Mao Zedong period, the theme of the times transfer from revolution and war to peace and development. The judgement of Mao Zedong towards international situation decides that China's national interest is at the core of national and political security or economic and cultural interest. For the view of Mao Zedong's national interest, see: Zhang Junguo: On the Analysis of the Main Influencing Factors of Mao Zedong's View of National Interest, pulished in Journal of Hunan University of Science \& Technology (Social Science Edition), issue 4, 2008, p. 12-13. For Deng Xiaoping's view of national interest, see: Yan Xuetong: Deng Xiaoping's View of National Interest, published in Contemporary International Relations, issue 7, 1994, p. 29-30. 
the development of international situation and the evolution of their interest cognition, when consistency/inclusiveness of core national interest cognition is inferior to divergence or one of the party's cognition is inferior to divergence, their strategic interaction will turn into a state of antagonism/negative competition. Hence, it's hard for them to gain positive and efficient feedback, their relations will be intense. During this period, Sino-Japanese relations is in a state of fluctuating. Accordingly, the importance of feedback assessment will be prominent. At this moment, China and Japan should assess the current strategic situation and inspect each other's core national interest. In this way, they will make the consistency/inclusiveness of interest cognition transcend divergence once again through strategic interaction seeking new strategic basis, thus shaping a scenario of cooperation and mutual benefits.

1. Fight Against the Soviet Union in Unity during the Cold War Period and the Later Inertial Fluctuation: The Strategic Basis of Sino-Japanese Relations from 1970 to 1997

1972 was a significant year in the history of Sino-Japanese relations, because it was regarded as the beginning of establishing diplomatic relations between modernized China and the major economy-Japan. Due to the Taiwan issue, cold war ideology and international landscape, both governments were in a state of isolation after 20 years of the founding of New China. Until 1972, Sino-Japanese relations began to have certain strategic basis initially. As the alleviation of Sino-Japanese relations and global expansion of containing the Soviet Union, feedback assessment was formed with no confrontation and common interest cognition. Therefore, the normalization of diplomatic relations between China and Japan marks the establishment of their strategic basis. And the exploration process of strategic basis was mainly reflected in Sino-Japanese strategic interaction from 1970 to 1972.

Japanese Sato government is beset with external and internal troubles. First of all, America in US-Japan alliance runs into the trouble of Vietnam War, and its strength is weaker than the Soviet Union, so Japanese national security suffers threat. The Soviet Union expands into the Middle East, South Asia, Central America and other regions taking advantage of the occasion that America falls into the trouble in Indo-China Peninsula. The outbreak of Zhenbao Island event symbolizes that the security situation in Northeast Asian region is tend to be intense, so does Japan in US-Japan alliance. Secondly, as an ally of Japan, America carries out the diplomatic policy of "top diplomacy" towards China. Japan's diplomatic strategy is deeply struck, but the Sato government is still excessively conservative towards the adjustment of policy to China, still adhering to the argument of "two Chinas". In this case, the court and the commonalty of Japan have different opinions upon the issues of reestablishing diplomatic relations with China. And there are signs of instability in Japan's political situation (Nobuo Kiyosaburo, 1980). Thirdly, in economy, though after three years since 1968, the actual growth rate of Japanese Gross National Product (GNP) was 12.1\%, which surpassed West Germany and ranked the second place in "western camp" followed by America. ${ }^{7}$ But Nixon government adopted U.S. dollar defense policy, expanding the gap between Japan and America in economy, ${ }^{8}$ and the subsequent oil crisis also shook the basis of Japanese

\footnotetext{
${ }^{7}$ While America advancing the Vietnam War, the dollar crisis deepened. In particular, America distributed a large number of dollars for military need in Southeast Asia. Japan aimed to export lots of commodities for these regions to make money. See: Kobayasi: The Post-war Economic History, translated by Sun Hanchao, etc. Beijing: The Commercial Press, 1992, p. 164. Shi Yinhong: American Intervention and War in Vietnam, Beijing: World Affairs Press, 1993, p. 262-265.

8 The influence of American strategy adjustment to Japan is called as "the Nixon Shock" by Japan. See: Lokibe Makoto: History of Japan-U.S. Relations, translated by Zhou Yongsheng, Beijing: World Affairs Press, 2012, p. 232.
} 
economic development. ${ }^{9}$

The above realistic questions urge China and Japan to inspect their own core interest from strategic perspective and put aside the divergence on ideology. Through exploration, both parties have found the cooperation basis successfully, that is to contain the Soviet Union and strengthen economic cooperation. Under this context, China and Japan realize the normalization of diplomatic relations quickly. It only takes 84 days from the founding of the Tanaka cabinet to the signature of Sino-Japanese Joint Statement (Makoto Iokibe \& Wu, 2012). In a word, from 1972 to a period after the ending of cold war, the strategic basis of Sino-Japanese relations can be reflected from the comparison of consistency/inclusiveness of core national interest in Table 1.

Table 1. Consistency/Inclusiveness Cognition of Core National Interest for China and Japan from 1970 to 1989

\begin{tabular}{|c|c|c|c|c|}
\hline $\begin{array}{c} \\
\text { Interest } \\
\text { Cognition } \\
\text { Nation and } \\
\text { Assessment }\end{array}$ & $\begin{array}{c}\text { Core Interest } \\
\text { One }\end{array}$ & $\begin{array}{c}\text { Core Interest } \\
\text { Two }\end{array}$ & Core Interest Three & $\begin{array}{c}\text { Core Interest } \\
\text { Four }\end{array}$ \\
\hline Japan & National Security & Economic Prosperity & Political Interest & Regional Stability \\
\hline China & National Security & $\begin{array}{c}\text { Economic } \\
\text { Development }\end{array}$ & Political Interest & Regional Stability \\
\hline Cognition & $\begin{array}{c}\text { Consistency: } \\
\text { strategic expansion } \\
\text { of the Soviet Union } \\
\text { poses great security } \\
\text { threat to China and } \\
\text { Japan }\end{array}$ & $\begin{array}{l}\text { Consistency: China and } \\
\text { Japan forms mutual } \\
\text { benefit and } \\
\text { collaboration system } \\
\text { and lays a solid } \\
\text { foundation for their } \\
\text { economic } \\
\text { development. }\end{array}$ & $\begin{array}{l}\text { Historical issues } \\
\text { inclusiveness and } \\
\text { sectional } \\
\text { differences of } \\
\text { territorial } \\
\text { sovereignty } \\
\text { (Taiwan) }^{10}\end{array}$ & $\begin{array}{c}\text { Consistency: } \\
\text { maintain regional } \\
\text { security, promote } \\
\text { economic } \\
\text { development and } \\
\text { establish safeguard } \\
\text { mechanism }\end{array}$ \\
\hline
\end{tabular}

We can see from the table 1 that during the strategic cooperation period of China and Japan from 1970 to 1989 , due to major countries shared almost the common interest in national security and economy, consistency/inclusiveness of both countries' core interest could be thought to transcend divergence, so they changed their cognition towards each other from previous hostility to "right ally" on geopolitics level. ${ }^{11}$ On diplomatic practice, it is also

\footnotetext{
9 Brzezinski points out the vulnerability of Japanese economic development, and believes that the development of Japanese economy is just "a flash in the pan". See: Lokibe Makoto: History of Japan-U.S. Relations, translated by Zhou Yongsheng, Beijing: World Affairs Press, 2012, p.230.

10 According to the third interpretation of Sino-Japanese Joint Statement by Japan, China and Japan are intend to put aside Taiwan issue proceeding from the whole situation.

11 Tanaka Kakuei thinks that if China, Japan and America establish the relationship of equilateral triangle, the peace of the Far East will come true. Japan's establishment of normal relationship with China is more likely to become security assurance than setting up NATO in Asia. See: Kazuko Mori: Sino-Japanese Relations: The Post-war towards New Era, Beijing: Social
} 
operated in a healthy way with very stable strategic cooperation basis. Though they have not completely reached agreement on Taiwan issue, cooperation on economy, culture and other areas have been carried out. On economy, China is at initial stage of reform and opening up. Hence, it gives priority to economic construction and is in urgent need of learning experience from advanced country. Meanwhile, it strives for assistance, direct investment and transfer of technology. Japan is an export-oriented economy, so it's of great significance for Japanese economic development to open up overseas market, especially the potential Chinese market. ${ }^{12}$ On this occasion, Japanese government provides China with official loan (ODA) at the annual interest rate of 3\%. From 1979 to 1984, Japanese government offered China government loan worth of 330 billion yen. In 1979, the determinate loan commitment was 50 billion Yuan, which contributed to the socialist modernization of China. ${ }^{13}$ The trading amount also soared between China and Japan, with 8.2 billion dollars in 1978. And in 1981, this number increased to 11.3 billion (accounting for $1 / 4$ of the total amount of China's foreign trade). In 1988, it reached 19.3 billion dollars (Zhang, 2006).

However, at the end of 1980s, as the conclusion of US-Soviet Cold-War, international system had undergone a fundamental shift. With the removal of common external security threat, the inherent backbone of Sino-Japanese cooperation became less clear and steady, the strategic basis was also impaired greatly. The consistency/inclusiveness of their core interest has weakened a lot, divergences and conflicts are emerging step by step. And the consistency/inclusiveness of their sectional core interest has tended to divergent and contradictory. In this process, they have reversion upon each other's cognition and repetition on strategic interaction. Subsequently, Sino-Japanese relations step into strategic feedback assessment period with fluctuating relationship. In the meantime, they conduct feedback assessment in good time, adjust external strategic interaction and try to reshape strategic basis that has been weakened to make a balanced relationship. The volatility of Sino-Japanese relations in this period of feedback assessment reflects in strategic interaction. In 1989, Japan joined the west to sanction China, so their exchanges fell into stagnation and affected economic and trade contact (Zhang, 2001). So far, from 1970 to 1997, the strategic basis built by interest cognition, strategic interaction and feedback assessment of China and Japan had gone through a "logic loop" (the "logic loop": seek for "right ally" with common interest Cognition- $>$ realize benign strategic interaction- $>$ run-in and consolidation of strategic basis$>$ the removal of common interest cognition- $>$ the appearance of antagonism strategic interaction- $>$ the damping of strategic basis- $>$ fluctuation and repetition of China-Japanese relations under feedback assessment) Under this circumstance, the fluctuating Sino-Japanese relations shall rely on new strategic basis.

Sciences Academic Press, 2009, p.69; Robert Ross, Negotiating Cooperation: The United States and China, 1969-1989, Stanford: Stanford University Press, 1995, p.150.

12 In 1970, the total amount of Sino-Japanese trade had reached 820 million dollars. By comparison, Japan invested 63 million dollars in Taiwan from 1953 to 1969. In order to prevent America from occupying Chinese market quickly, Japan contends that it's acceptable to sacrifice Taiwan in economy. See: Shinobu Seizaburo: History of Japanese Diplomacy, translated by Institute of Japanese Studies, Tianjin Academy of Social Sciences, Beijing: The Commercial Press, 1980, p. 904.

13 As of February, 2016, until 1972 the amount of loan of Japanese government assistance to China had been about 3.3164 trillion yen, 157.2 billion yen for project assistance and 181.7 billion yen for technology cooperation. http://www.mofa.go.jp/policy/oda/region/e_asia/china/index.html, login time: March, 18, 2017. 
2. The Policy of "Separating Economy from Politics" during Anti-terrorist Period: The Strategic Basis of Sino-Japanese Relations from 1998 to 2011

In 1998, China and Japan announced the third political document together, the Sino-Japanese Joint Declaration. Both countries tried to reshape the strategic basis through interaction and practice, and established the strategic basis of Sino-Japanese relations toward the $21^{\text {st }}$ century in documents. However, when entering into the $21^{\text {st }}$ century, the reshaping of the two countries' strategic basis wasn't been carried out as planned. In 2001, Mr Koizumi visited the Yasukuni Shrine. Thus, the relations of Japan with its neighbors including China were intense. Nonetheless, China didn't end the high-level dialogues between the two countries, as well as insisted on "taking history as a mirror and looking toward the future". In October of that year, Jiang Zemin held meetings with Mr Koizumi in Beijing and Shanghai successively. And the two countries showed that they would further promote friendly exchanges and cooperation between China and Japan in all fields and at all levels.

However, it's difficult to fully support the long-term development of bilateral relations only through the exchange visits of leaders. Therefore, the Chinese leaders continued to explore a new strategic basis for promoting the bilateral relations from the perspective of national interests. Firstly, Chinese government realized that it's necessary to achieve political stability, national security, economic modernization and other core national interests. And deepening reform is the only way to keep economic development with a sustainable, rapid and sound state, as well as to constantly improve people's living standards (The Central People's Government of the People's Republic of China, 2000). Meanwhile, it's crucial to have a stable Sino-Japanese relations with multi-field cooperation. Secondly, after the Cold War, the theme of the times---peace and development, became more prominent without any change. In particular, after the "9.11" terrorism attacks, China and Japan provided intelligence and diplomatic support for the United States' global counter-terrorism strategy (Kissinger \& Hu, 2015). On the denuclearization of the Korean Peninsula, China and Japan also maintained regional security and stability through the Six-Party Talks on the Korean nuclear issue. At the same time, China and Japan also strengthened cooperation in defense and security, and the defense departments of the two countries conducted several security and defense consultations ( $\mathrm{Li}, 2007)$. Based on the above efforts made by the two sides, in 2003, $\mathrm{Hu}$ Jintao once again stressed that while developing the Sino-Japanese relations in the new century and striving to expand the common interests, it's important to pay more attention to and properly deal with each other's concerns in particular the historical and Taiwan issues. Ultimately, China insisted on the strategy of carrying out comprehensive market-oriented reform, speeding opening-up and actively integrating into the international system in order to realize its core interests. Essentially, it's also a way to accelerate the economy development of Japan instead of recession and start the self-discipline economy recovery, which met the core national interests of Japan. ${ }^{14}$ In a word, the strategic basis of Sino-Japanese relations from

\footnotetext{
14 If there was a comprehensive and competitive confrontation between China and Japan due to the historical and Taiwan issues, it had been impossible for Japan to smoothly achieve economic recovery under the case that the collapses of Japan's "bubble economy" had got its national economy into a long-term recession. Thus, there was a tendency of "Cold Politics and Warm Economy" on Sino-Japanese relations, which conformed to the core national interests of Japan.
} 
1998 to 2011 during Japan followed the "Pivoting to Asia-Pacific" strategy of the US, ${ }^{15}$ can be reflected from the comparison of consistency/inclusiveness of the two countries' core interests in table 2.

Table 2. Consistency/Inclusiveness Cognition of Core National Interest for China and Japan from 1998 to 2011

\begin{tabular}{|c|c|c|c|c|}
\hline Interest Cognition & $\begin{array}{l}\text { Core Interest } \\
\text { One }\end{array}$ & $\begin{array}{l}\text { Core Interest } \\
\text { Two }\end{array}$ & $\begin{array}{c}\text { Core Interest } \\
\text { Three }\end{array}$ & $\begin{array}{c}\text { Core Interest } \\
\text { Four }\end{array}$ \\
\hline Japan & $\begin{array}{l}\text { Economic } \\
\text { Prosperity }\end{array}$ & $\begin{array}{l}\text { National } \\
\text { Security }\end{array}$ & Political Interest & Regional Stability \\
\hline China & $\begin{array}{c}\text { Economic } \\
\text { Development }\end{array}$ & $\begin{array}{l}\text { National } \\
\text { Security }\end{array}$ & Political Interest & Regional Stability \\
\hline Cognition & $\begin{array}{l}\text { Consistency: } \\
\text { China and } \\
\text { Japan were } \\
\text { highly } \\
\text { complementar } \\
\text { y and mutually } \\
\text { beneficial }\end{array}$ & $\begin{array}{l}\text { Inclusiveness: } \\
\text { the anti-terrorist } \\
\text { issue, the } \\
\text { Korean nuclear } \\
\text { issue and others } \\
\text { promoted } \\
\text { consultation } \\
\text { and cooperation } \\
\text { between China } \\
\text { and Japan }\end{array}$ & $\begin{array}{l}\text { Divergences } \\
\text { were increased } \\
\text { in history, } \\
\text { territorial } \\
\text { sovereignty (ie, } \\
\text { Taiwan, Diaoyu } \\
\text { islands) and so } \\
\text { on }\end{array}$ & $\begin{array}{l}\text { China and Japan } \\
\text { carried out } \\
\text { cooperation in } \\
\text { regional security, } \\
\text { economy and } \\
\text { other fields, and } \\
\text { showed } \\
\text { inclusiveness in } \\
\text { building regional } \\
\text { system }\end{array}$ \\
\hline
\end{tabular}

We can see from table 2 that China and Japan regarded the policy of "separating economy

15 In 2011, Obama, president of the United States, announced that the Us was a pacific power and would consolidate the position of the Us in Asia. Japan began to implemented the strategy through cooperating with the Us during the Noda's cabinet administration, which was further implemented during the Abe's cabinet administration.

${ }^{16}$ Since the beginning of the new century, in terms of the diplomacy in Southeast Asia, Japan has regarded China as the obstacle to acquire its dominant power in East Asia, which is a concrete manifestation of focusing on the "national interests" in Japanese diplomatic strategy. See: Li Jianmin: History of Sino-Japanese Relations After the Cold War, Beijing: China Economic Publishing Press, 2007, p.288. 
from politics" as the strategic basis from 1998 to 2011. During the strategic interactions of these years, the consistency/inclusiveness of the two countries' core interests surpassed the divergences. However, the cognition in core interests was impaired than that of last period. In particular, when the international security situation was greatly eased in the Post-Cold War era, the divergences of the two countries on political interests, especially on territorial sovereignty and history, were increased. And there was a competitive situation in the dominance of regional system. Even so, there is no doubt that economic development and prosperity still top the core national interests of the two countries. The cognition of China and Japan on each other gets rid of the influence of the fluctuating state in the 1990s, and each other has also established the strategic relationship of mutual benefit. Stable diplomatic interaction embodies the stable relations of China and Japan. Therefore, the relations between the two countries is truly based on the policy of "separating economy from politics".

Due to the cognitive divergence of the two countries transcended the consistency/inclusiveness on core national interests, the strategic interactions of the two countries turned into a state of antagonism/negative competition. And the strategic distrust of both sides intensified and the Sino-Japanese relations became intense. It's easy to find that the strategic distrust forces their strategic basis established on interest cognition, strategic interaction and feedback assessment to go through a "logic loop" (seek for common interest cognition- $>$ realize benign strategic interaction- $>$ run-in and consolidation of strategic basis$>$ the removal of common interest cognition- $>$ the appearance of antagonism strategic interaction- $>$ the damping of strategic basis- $>$ fluctuation of China-Japanese relations under feedback assessment). Meanwhile, there is a tendency of transition from "Cold Politics and Warm Economy" to "Cold Politics and Cold Economy" on Sino-Japanese relations.

\section{The America's Asia-Pacific Rebalance Strategy and the "Strike Led by Donald John Trump": The Probability of Reshaping the Strategic Basis of Sino-Japanese Relations}

Since 2012, Japan has identified itself as a part of the America's Asia-Pacific rebalance strategy, which is clearly intended to contain China's rise. And the new president of the United States, Donald Trump, has made it clear that he will adjust the Asia-Pacific rebalance strategy which was energetically pursued during the Obama term. However, Japan's strategic inertia and cognition cause it difficult to make a major adjustment in a short time after Trump proposes the new Asia-Pacific strategy and implements the adjustment. Essentially, the strategic distrust as an issue on interest cognition has become a major problem in Sino-Japanese relations and has obviously impaired the strategic basis of bilateral cooperation. It shows that the role in Sino-Japanese relations has been greatly different from that in 1970 or 1989 because of the gap in power between the two countries. In the past, Japan was a leader in bilateral relations. Now, with China's rise as a global power, it's inevitable for Sino-Japanese relations to change accordingly. Based on four political documents between China and Japan, China proposes to advance Sino-Japanese relations of strategic mutual benefit. So, how should Japan give feedback assessment to China's proposal? How can the strategic basis of Sino-Japanese relations be reshaped? In order to answer the above questions, we can analyze them with the three aspects of interest cognition, strategic interaction and feedback assessment in the theoretical framework of this paper. 


\section{Mll Macrothink}

International Journal of Human Resource Studies

ISSN 2162-3058

2020, Vol. 10, No. 4

The cognition of Japan on core national interest has been changed by a surge of American and domestic pressure. On economy, Japan is in a state of depression, hardly expecting a long-term prosperity (Akira Kojima, 2015). In 2008, when the international financial crisis occurred, Japan's economy suffered a shock with enormous debt and serious decline of growth rate, which made it more difficult for Japan to realize the economic transformation. ${ }^{17}$ Furthermore, the prolonged feebleness of economic growth had also profoundly affected Japanese society, which began to be conservative. ${ }^{18}$ Due to the influence of American realism theory, Japan still held a skeptical attitude towards the rise of China, bearing heavy external pressure (Yamamoto Yoshinobu, 2015). In 2012, Shinzo Abe was reelected as prime minister of Japan and began to gradually adjust interest cognition, so that political interest and regional stability became more important in core national interests. For reshaping Japan's confidence, consolidating its ruling position and eliminating people's general insecurity sense, the Abe's cabinet adopted the "abenomics" with short-term stimulus effect on the economy and vigorously pursued the "TPP negotiation led by the Us" to adjust social pressure. In strategy, deeply influenced by the eastward shift of American strategy, Japan makes its cognition on regional stability establish on the assumption of "China Threat Theory" and believes that there is a security dilemma in East Asia (National Security Strategy, 2013). As a result, Japan has strongly pursued the idea of "active defense" for some time. On the one hand, it takes "active actions" on the Diaoyu islands issue. ${ }^{19}$ On the other hand, it also takes "excessive actions" on the South China Sea issue. ${ }^{20}$ As the strategic cornerstone of America's "gateway to Asia", Japan chooses the "zero-sum" thinking with a deep meaning of "Thucydides's trap" on interest cognition, and unilaterally safeguards its own partial national interests. $^{21}$

Under the background of the strategic adjustment of the Us during the Obama term, the interest cognition of Japan has been changed. According to the above-mentioned situations, China believes that the external environment long relied for peaceful development has undergone complicated changes. For one thing, America is trapped at home and abroad. ${ }^{22}$ Therefore, America has adjusted its grand strategy, which is the eastward shift of America's strategic center. The Asia-Pacific region has become a place where all stakeholders focus on.

\footnotetext{
17 "Abenomics" refers to use a series of economic stimulus policies to achieve the economic growth, which cannot fundamentally solve the structural problems restricting the Japanese economy, including the hollowing out of labor force, finance and industry. So it's hard to be optimistic for the long-term prospects of "Abenomics".

18 Japanese generally have a sense of insecurity and are reluctant to face globalization. See: Men Honghua: Japan's Changing Situation and the Trend of Sino-Japanese Relations, published in World Economy and Politics, 2016, Issue 1, p.72-90.

${ }^{19}$ Since the Noda's cabinet announced the decision of "purchasing islands" in 2012, China and Japan have faced off several times in the waters near the Diaoyu Islands. The Noda's cabinet also named the outlying islands after the exclusive economic zone, which included four islands and reefs in the Diaoyu Islands.

20 Japan not only provided 10 patrol ships to the Philippines with a loan of about 18.7 billion yen (about 1.24 billion yuan), but also carried out two joint military exercises with the Philippines so that the military security confrontation in regions was increased. Furthermore, Japan took a series of measures not conducive to regional security and stability at the "South China Sea Arbitration" and the "ASEAN Summit".

${ }^{21}$ Under the premise of self-construction of the "China Threat Theory", Japan envisaged relying on American strategies for Asia-Pacific region to enhance its dominance in the region. Meanwhile, Japan aligned with regional countries and jointly developed strength diplomacy with China in order to maintain the core interests in economy and politics, as well as to safeguard its national security and regional stability. But the results show that the strategic interaction under this interest cognition is not an effective way to safeguard national interests, and even some of its own interests are damaged.
} 
Besides, the sensitivity of regional affairs including security, economic cooperation and institutional construction has been increased, and the concerns and pressures in bilateral and multilateral diplomacy have been gained. After Trump was elected as president, America has tended to be "isolationist" in foreign relations, and its foreign military and security strategies have been in a shrinking situation. However, the basic logic of America's strategic adjustment is to make domestic and foreign policies in accordance with its national interests. Thus, the economic factor is American core consideration. And the fact that the gradually rising of the East Asian economy has decided that America will still focus on the Asia-Pacific region in foreign strategy adjustment. For another thing, the security situation around East Asia has been changed and become more complicated. The importance of national security, political interests and regional stability in core interests has been gradually strengthened. Hence, China believes that it's hard to safeguard the economic interest if the above-mentioned interests can't be guaranteed (Xinhuanet, 2013). In conclusion, China and Japan are in a new strategic exploration period, and the divergences between the two countries have transcended the consistency or inclusiveness in the cognition of core national interests. Therefore, the current core issue lies in the strategic interaction and effective feedback assessment, which can make interest cognition between China and Japan, especially Japan, return to the track of strategic mutual benefit.

According to what have been mentioned above, the author believes that the core tasks of Sino-Japanese relations at the present are to seek solutions for the practical problems highlighted in the interest cognition and strategic interaction between the two sides, as well as to realize the reconstruction of strategic basis through concept innovation and diplomatic interaction. Therefore, China and Japan, on the basis of the four-point principled agreement (Lei, 2014), should adhere to the ideas of mutual respect, management and control of divergences, and win-win cooperation, re-examine their own interests and interaction model, and make appropriate adjustments and innovations. First of all, China should make it clear to the outside world that the sovereignty issue is China's core interest, ${ }^{23}$ so as to prevent its neighbors from misunderstanding its interests and misjudging the situation. Secondly, China should take the initiative to shoulder more international responsibilities based on reality. ${ }^{24}$ Under the circumstances that the emerging of strategic contraction and protectionism in the United States has endangered global trade liberalism, China should provide high-quality public products for regions and world, promote to carry out the strategy of "the Belt and Road Initiative", actively participate in the development of regional security, economic rules and play a role in construction to achieve win-win cooperation and common development in regions.

\footnotetext{
${ }^{23}$ On the issue of Diaoyu Islands, the outside world had discussions on China's core interests. However, China didn't clearly state to Japan that the Diaoyu Islands belongs to a part of "China's core interests" until August 20, 2013. There are also some different opinions on this issue. See: Expert: Compared with the Overall Situation of China and Japan, the Diaoyu Islands Is Not a Core Interest, http://mil.huanqiu.com/observation/2012-09/3136525.htm; Does the Chinese Government Really Claim that the Diaoyu Islands Is a Part of Its "Core Interests?, http://thediplomat.com/2013/04/senkakudiaoyu-islands-a-core-interest-of-china/.

${ }_{24}$ Taking responsibility is not the same as "aggressive". See: Wang Hao: Interest, Cognition and Interaction: the Analysis of the Reasons for the Evolution of Sino-Japanese Relations, published in the World Economy and Politics, 2014, Issue 10, p.114.
} 


\section{References}

$\mathrm{Wu}, \mathrm{J}$. (2013). On the path choice of Reconstruction of strategic mutual trust between China and Japan. Japanese Studies, 4, 3-12.

Wang, J., \& Li, K. (2012). Strategic Mutual Doubt between China and the United States: Analysis and Response. Beijing: Center for International Strategic Studies, Peking University.

Sun, C. (2009). China's Development and Sino-Japanese Relations. Japanese Studies, 2, 36-37.

Jervis, R., \& Qin, Y. (2003). Perception and Misperception in International Politics. Beijing: World Knowledge Press, 432-433.

Liu, J. (2012). Japan's national interest outlook, foreign strategy and China policy. Diplomatic review, 5, 12-22.

National security strategy. (2015). Japan-us alliance in the new security environment -National interests, National strategy and Japan-US alliance. Retrieve from http://www.mod.go.jp/j/publication/ronbun/18/02-02.pdf

National security strategy. (2013). Retrieve from http://www.kantei.go.jp/jp/kakugikettei/2013/_icsFiles/afieldfile/2013/12/17/20131217-1_1. pdf

Yan, X. (1996). China National Interest Analysis. Tianjin: Tianjin People's press, 303-306.

State Council of China. (2011). "China's Peaceful Development" White Paper. Retrieve from http://www.gov.cn/jrzg/2011-09/06/content_1941204.html

Nobuo Kiyosaburo., \& Institute of Japanese Studies, Tianjin Academy of Social Sciences Translated. (1980). Japanese Diplomatic History. Beijing: The Commercial Press, 901-903.

Makoto, I., \& Wu, W. Translated. (2012). Japanese Diplomatic History After The War. Beijing: World Knowledge Press, 119. https://doi.org/10.4324/9780203870969

Zhang, L. (2006). Centenary of Sino-Japanese Relations. Beijing: World Knowledge Press, 425-427.

Zhang, J. (2001). The Development and Characteristics of Sino-Japanese Economic and Trade Relations in the 1990s. Japanese Studies, 3, 29-30.

The Central People's Government of the People's Republic of China. (2000). The Central Committee of the Communist Party of China on the formulation of the tenth five-year plan for national economic and social development. Retrieve from http://cpc.people.com.cn/GB/64162/71380/71382/71386/4837946.html

Kissinger., \& Hu, L. Translated. (2015). On China. Beijing: CITIC Press, 482.

Li, J. (2007). History of Sino-Japanese Relations after the Cold War. Beijing: China Economic Press, 368.

Akira Kojima. (2015). Between the 2020 Tokyo Olympics and the 1964 Olympics: A sustainable development model beyond economic measures.

Yamamoto Yoshinobu. (2015). Belt and Road from the perspective of the rise of China and the

from 


\section{Macrothink}

International Journal of Human Resource Studies

ISSN 2162-3058 2020, Vol. 10, No. 4

http://thinktank.php.co.jp/wp-content/uploads/2016/05/policy_v9_n70.pdf

National Security Strategy. (2013). Retrieve from http://www.cas.go.jp/jp/siryou/131217 anzenhoshou.html.

Xinhuanet (2013). Xi Jinping diplomatic message is that he is strong but not tough. Retrieve from 2013-01-31. https://doi.org/10.1055/s-0032-1326533

Lei, J. (2014). Reached a four-point principled consensus, China and Japan agree to gradually restart dialogue. Retrieve from. http://china.cankaoxiaoxi.com/2014/1108/558034.shtml

\section{Copyright Disclaimer}

Copyright for this article is retained by the author(s), with first publication rights granted to the journal.

This is an open-access article distributed under the terms and conditions of the Creative Commons Attribution license (http://creativecommons.org/licenses/by/4.0/). 